FORMS OF MODERNITY: DON QUIXOTE AND MODERN THEORIES OF THE NOVEL 
This page intentionally left blank 
RACHEL SCHMIDT

\section{Forms of Modernity}

Don Quixote and Modern

Theories of the Novel

UNIVERSITY OF TORONTO PRESS

Toronto Buffalo London 
(C) University of Toronto Press Incorporated 2011

Toronto Buffalo London

www.utppublishing.com

Printed in Canada

ISBN 978-1-4426-4251-5 (cloth)

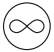

Printed on acid-free, $100 \%$ post-consumer recycled paper with vegetablebased inks.

\section{Library and Archives Canada Cataloguing in Publication}

Schmidt, Rachel, 1963-

Forms of modernity: Don Quixote and modern theories of the novel /

Rachel Schmidt.

(University of Toronto romance series)

Includes bibliographical references and index.

ISBN 978-1-4426-4251-5

1. Fiction - History and criticism. 2. Cervantes Saavedra, Miguel de, 15471616. Don Quixote. I. Title. II. Series: University of Toronto romance series.

PN3491.S35 $2011 \quad 809.3 \quad$ C2010-906446-1

This book has been published with the help of a grant from the Canadian Federation for the Humanities and Social Sciences, through the Aid to Scholarly Publications Program, using funds provided by the Social Sciences and Humanities Research Council of Canada.

Canada Council for the Arts
Conseil des Arts du Canada

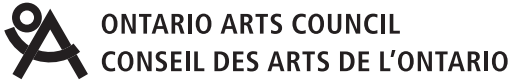

University of Toronto Press acknowledges the financial assistance to its publishing program of the Canada Council for the Arts and the Ontario Arts Council.

University of Toronto Press acknowledges the financial support of the Government of Canada through the Canada Book Fund for its publishing activities. 
To Ken, Esther, Abigail, Mom, Dad, Luther, and JoannaThanks for being there. 
This page intentionally left blank 